\title{
Seasonal Parasitic Infestations and their Close Relationship to Immune Suppression in Cultured Sea Bass (Dicentrarchus labrax l) and Sea Bream (Sparus auratus)
}

\author{
Khalil RH ${ }^{1 *}$, Medhat S Shakweer ${ }^{2}$, Hanan A Ghetas ${ }^{3}$, Khallaf M $^{4}$, Sherif El Shanat ${ }^{1}$ and Amira AE D Omar ${ }^{5}$ \\ ${ }^{1}$ Fish diseases and Management, Department of Internal medicine, Infectious and Fish diseases, Faculty of Veterinary Medicine, Mansoura University, Egypt \\ ${ }^{2}$ Aquatic Animal Medicine and Management Department Faculty of veterinary medicine-Sadat City University, Egypt \\ ${ }^{3}$ Department of Poultry and Fish, Faculty of Veterinary Medicine, Alexandria University, Egypt \\ ${ }^{4}$ Department of parasitology, Faculty of Veterinary Medicine, Alexandria University, Egypt \\ ${ }^{5}$ Department of Fish Diseases and Management, Faculty of Veterinary Medicine, Kafr El-Sheikh University, Kafr El-Sheikh, Egypt
}

Received: 制 June 21, 2018; Published: 盋July 10, 2018

*Corresponding author: Khalil RH, Fish diseases and Management, Department of Internal medicine, Infectious and Fish diseases, Faculty of Veterinary Medicine, Mansoura University, Egypt

\begin{abstract}
The study identified and compared the prevalence and intensity of parasites of sea bream (Sparus auratus) and sea bass (Dicentrarchus labrax L.) from culture environments during different season. One hundred and twenty samples from each of sea bream and sea bass ( 30 from each type of fish per season) were collected and gross observations were carried out to check for physical abnormalities and presence and identification of parasites as well as another 20 apparently healthy samples from each of sea bream and sea bass. The water samples were also collected to evaluate the different water quality. The samples were dissected and the skin and gills were examined for parasites presence, prevalence and intensity. Two classes of parasites were recovered namely protozoans [1] and two types of trematodes namely; Monogenea (Dactylogyrus sp and Gyrodactylus sp). Cultured sea bream and sea basshad higher parasitic infections, intensity, prevalence and the parasites were significantly different in the tissues and organs. Blood and serum samples were collected for determine of some immune parameters namely, total protein, globulin, lysosomal activity in parasitized and non - parasitized fishes. The all previous mentioned immune parameters were mostly reduced. Finally the histopathological section taken from different external organs revealed parasitic stages.
\end{abstract}

Keywords: Sea Bream; Sea Bass; Water Quality; Cryptocaryon Irritans; Dactylogyrus Sp; Gyrodactylus Sp; Immune Parameters; Histopathological; Fish Mortality; Parasite Fauna

\section{Introduction}

However the intensification of culture systems and resultant deterioration in the environment has been associated with an increase in parasitic and infectious disease problems. Infectious diseases are caused by parasites, but host and environmental factors also play a role in their occurrence [2]. Parasite infections in fish causes production and economic losses through direct fish mortality; reduction in fish growth; reproduction and energy loss; increase in the susceptibility of fish to disease and predation; and through the high cost of treatment [3]. Although fish suffered bacterial, fungal diseases, the prevalence of different parasites in the fish farm might be due to improper stocking density [4]. Not only that the infected brood stocks might transfer ecto parasites from farm to farm their fry and fingerlings are used to stock uninfected ponds [5]. The deaths of fish seeds were mainly due to extreme low and high temperature of winter and summer respectively. Parasitic infections often give an indication of the quality of water since parasites generally increase in abundance and diversity in more polluted waters [6]. However, five factors namely age, diet, abundance of fishes, independent number of a parasite within the fish and season, directly influence the parasite fauna of fishes (Kabata, 1985). The parasitic community of fish show considerable variation with the environmental conditions in which fish live [7].

Monogeneans are the most ubiquitous and abundant group of helminthes parasites in the aquatic environment [8]. They are predominantly ecto parasitic on gills and skin of fishes [9]. Among the monogenea, Dactylogyrus sp. was mostly observed in gillsas compared to Gyrodactylus sp. which corroborate the earlier view [10]. Monogeneans have a series of hooks that enable them to attach while feeding. Morbidity and mortality epidemics in cultured fish caused by excessive parasite loads are associated with crowding, inadequate sanitation and deterioration of water quality Kurva and Gadadhar[29]. El- Seify et al.[25] stated that the high incidence and prevalence of parasitism during summer season than in winter season. Also, reported that the high incidence of parasites occurs 
especially in areas with deteriorations of the water quality. On the other hand Reed et al. 2005 noted that some parasites were reported on separate season, as in summer season Gyrodactylus, were isolated, while in the winter season the researcher recorded that the Dactylogyrus and Cryptocaryon were found. Also, mentioned that the temperature play role in hatching of eggs of parasites to Dactylogyrus spp. and Gyrodactylus also.

Cryptocaryon irritans (Cryptocaryon) is a ciliated, protozo anparasite which causes a disease known as marine "ich" or marine "white spot" disease in wild and cultured marine fishes at temperatures between 15 and $30^{\circ} \mathrm{C}[1]$. The length of the entire life cycle varies, depending upon a number of factors, including strain of Cryptocaryon, temperature, salinity, and fish host [11]. Temperatures for optimal growth of most strains of Cryptocaryon appear to be about $23-30^{\circ} \mathrm{C}[26]$, although active infections at $15^{\circ} \mathrm{C}$ have been documented [12]. A more recent study demonstrated that the Cryptocaryon parasite can be found on the fish, and survived dormant for $4-5$ months at $12^{\circ} \mathrm{C}[13]$. Fish that survive a Cryptocaryon infection develop immunity, which can prevent significant disease for up to 6 months [1]. In bony fish, blood chemistry represents important parameters to evaluate the general physiological condition of the body, used specially as stress indicators [14]. In clinical chemistry, Total serum protein represents the most important indicator of the nutritional condition of the organism and of fish health condition [15].

The total protein concentration in fish serum differ, depending on a series of factors such as food diet, species, season, degree of sexual maturity, water temperature [16]. The levels of globulin and total protein indirectly reflect the condition of specific humeral immunity [17]. Albumin is an important serum protein for transportation of steroid hormones [18]. Ahmed and Ali [19] found that the withstand infestation of light intensity of ecto parasites [1-32] without any significant differences in serum total protein, albumin and globulin. The aim of this study is to identify the external parasites in sea bass and sea bream, and compare the prevalence, intensity in different season and immune suppression effects of parasites from the cultured environments in Domitte region south Egypt.

\section{Methodology}

A total of 120 live fish samples comprising of two species of sea bream (Sparus auratus) and sea bass (Dicentrarchus labrax L.) were collected from private marine water farm at Domitte province, Egypt during summer and winter season (30 from each species during summer and winter season). Gross physical examination of the external features of the samples were done for abnormalities (if any); and the fish were transported in a 25 liters plastic containers to the laboratory. The specimens were kept in glass tanks $(72 \times 30$ x $35 \mathrm{~cm}$ ) filled with salt water (35\%o). The samples were separated into species and weighed (g) where sea bass and sea bream with weights range of $130 \pm 20 \mathrm{~g}$ and $100 \pm 15 \mathrm{~g}$ respectively.

The outer layer of the skin were then scraped from the right and left sides of the back and posterior of the fish body, transferred to a slide, diluted with a drop of sterilized water, cover-slipped and examined under a microscope (Olympus CX40).

Large parasites were expressed by their absolute numbers, while the microscopic parasites were expressed by decanting serially and determining their minimum, maximum and average numbers in each field of view of microscope at a definite magnification. Smears were made from the samples of the skin and gills. These specimens were dissolved in Petri dishes with few drops of $9 \%$ saline solution which kept the parasites alive. Smear was place on sterilized slide and viewed under low and high power (400 X) magnification. Descriptive analysis was used to evaluate the data obtained. Level of significance of the mean difference on prevalence and intensity of parasites on sea bream and sea bass were carried out using T-test (SPSS version 15.0).The Parasitic Frequency Index (PFI) was calculated (Tables $3 \& 5$ ) by taking the percentage of the number of hosts infected by an individual parasite species against the total number of hosts examined in a particular area under investigation. The frequency indexes were further classified into rare 0.1 9.9\%), occasional (10-29.9\%), common (30-69.9\%) and abundant (70-100\%) as per [21]. Prevalence was estimated following the formulae proposed by $[21,22]$ as:

\section{Total number of infected fishes}

\section{F1. Prevalence $(\%)=$ Total No of fish hosts examined $\times 100$}

Determination of severity of infection (Table 1) was estimated as proposed by [22,23] and Phenotypic Characterization of Monogenic and Cryptocaryon irritans Parasites noted down in the (Table 2).Representative water samples were taken from different areas and depths accompanied with the fish samples, were succumbed to Physico-Chemical. In addition to the previous mentioned parameters the blood and serum samples were collected to investigate the different immune parameters (total protein (g/dl); albumin (g/dl); globulin (g/dl) and lysozyme activity) in parasitized and non-parasitized sea bream and sea bass. Also, samples from skin and gills examined for histopathological study. During this research the Kits for total protein and serum albumin (Pasteur, Lab, France) were commercially available from local scientific distributors in Egypt. Also lyophilized Micrococcus lysodekticus used for serum lysozomal activity (Sigma M 3770).

Table 1: Results of water quality assay in infected sea bream and seabass during summer and winter season in cultured conditions comparison with permissible levels.

\begin{tabular}{|c|c|c|c|}
\hline \multirow{2}{*}{ Water parameters } & \multicolumn{2}{|c|}{ Results } & \multirow{2}{*}{ Permissible limits } \\
\cline { 2 - 4 } & Summer season & Winter season & - \\
\hline Temperature ${ }^{\circ} \mathrm{C}$ & $2.36 \pm 28.5$ & $1.87 \pm 17.3$ & $0.01 \mathrm{mg} / \mathrm{L}$ \\
\hline Unionized ammonia (NH3) (mg/L.) & $0.0014 \pm 0.03$ & $0.0001 \pm 0.01$ & $0.01 \mathrm{mg} / \mathrm{L}$ \\
\hline Nitrite (NO2) (mg/L.) & $0.0011 \pm 0.02$ & $0.0001 \pm 0.01$ & \\
\hline
\end{tabular}

Cite this article: Khalil R, Medhat S S, Hanan A G, Khallaf M, Sherif E S. Seasonal Parasitic Infestations and their Close Relationship to Immune Suppression in Cultured Sea Bass (Dicentrarchus labrax l) and Sea Bream (Sparus auratus). Biomed J Sci\&Tech Res 6(4)- 2018. BJSTR. MS.ID.001376. DOI: 10.26717/ BJSTR.2018.06.001376. 


\begin{tabular}{|c|c|c|c|}
\hline PH & $0.87 \pm 8.2$ & $0.62 \pm 7.8$ & $8.0-8.5$ \\
\hline Salinity (PPT) & $3.17 \pm 38.7$ & $1.39 \pm 17.5$ & \\
\hline Organic matter (mg/L.) & $0.157 \pm 2.03$ & $0.005 \pm 0.66$ & $2-3 \mathrm{mg} / \mathrm{L}$ \\
\hline Hydrogen Sulphate (mg/L.) & $12.17 \pm 189.7$ & $9.81 \pm 53.7$ & $70-120 \mathrm{~L}$ \\
\hline
\end{tabular}

Table 2: Phenotypic Characterization of monogenean and Cryptocaryon irritans parasite.

\begin{tabular}{|c|c|c|}
\hline Cryptocaryon irritans(Figure 4) & Dactylogyrussp(Figure 3) & Gyrodactylussp(Figure 3) \\
\hline $\begin{array}{c}\text { - has Cytostome in the anterior portion, has } \\
\text { horse shoe like macronucleus, has micro } \\
\text { nuclease is difficult to be stained }\end{array}$ & $\begin{array}{c}\text { Haptor with 14 marginal hooks, squamodisc } \\
\text { absent }\end{array}$ & $\begin{array}{c}\text { Haptor with 16 marginal hooks, squamodisc } \\
\text { present }\end{array}$ \\
\hline $\begin{array}{c}\text { - Cilia with non-specific arrangement, its size } \\
50-100 \mu \mathrm{m} \text { and ovoid }\end{array}$ & $\begin{array}{c}\text { The anterior end is provided with two pairs of } \\
\text { eye spots }\end{array}$ & No eye spots. \\
\hline & $\begin{array}{c}\text { Oviparous, laying eggs and live as parasites, } \\
\text { particularly in gills }\end{array}$ & Viviparous and liberates live young worms \\
\hline & Head is scalloped. & V shaped head (bi lobed) \\
\hline - Infested marine fish only & Parasitize particularly the gills & Parasitize the skin and more rarely the gills \\
\hline & Infested both marine and freshwater fish & Infested both marine and freshwater fish \\
\hline
\end{tabular}

\section{Results}

Results of water quality assay in infected sea bream and sea bass during summer and winter season: (Table 1)shows significant differences $(\mathrm{p} \leq 0.05)$ between the different seasons. Water temperature was different during different seasons 28.5 and $17.3^{\circ} \mathrm{C}$ in summer and winter season respectively. Water $\mathrm{pH}$ remained between 8.2 and 7.2. In this study, Un-ionized form of ammonia (N$\mathrm{NH}_{3}$ ) both nitrite $\left(\mathrm{N}-\mathrm{NO}_{2}-\right)$ and nitrate $\left(\mathrm{N}-\mathrm{NO}_{3}-\right.$ ) was significantly higher $(\mathrm{p} \leq 0.05)$ in the summer more than winter season and 0.03 and $0.01 \mathrm{ppm}$ in summer and winter season, respectively. Hydrogen sulphide $\left(\mathrm{H}_{2} \mathrm{~S}\right)$ values ranged from 189.7 and $53.7 \mathrm{mg} / \mathrm{l}$ in summer and winter season, respectively and these results were higher than the acceptable level of cultured marine fish.
Results of clinical signs of sea bass and sea bream infested by different external parasite Results of clinical signs of sea bass and sea bream infested by monogenetic trematoda showed lethargic, swim near the surface, seek the sides of the pool or pond, and their appetite dwindles. They may be seen rubbing the bottom or sides of the holding facility (flashing). The skin where the flukes are attached shows areas of scale loss and may ooze a pinkish fluid. Gills may be swollen and pale, respiration rate may be increased, and fish will be less tolerant of low oxygen conditions. "Piping", gulping air at the water surface, may be observed in severe respiratory distress. Large numbers ( $>10$ organisms per low power field) of monogeneans on either the skin or gills may result in significant damage and mortality (Figure 1).

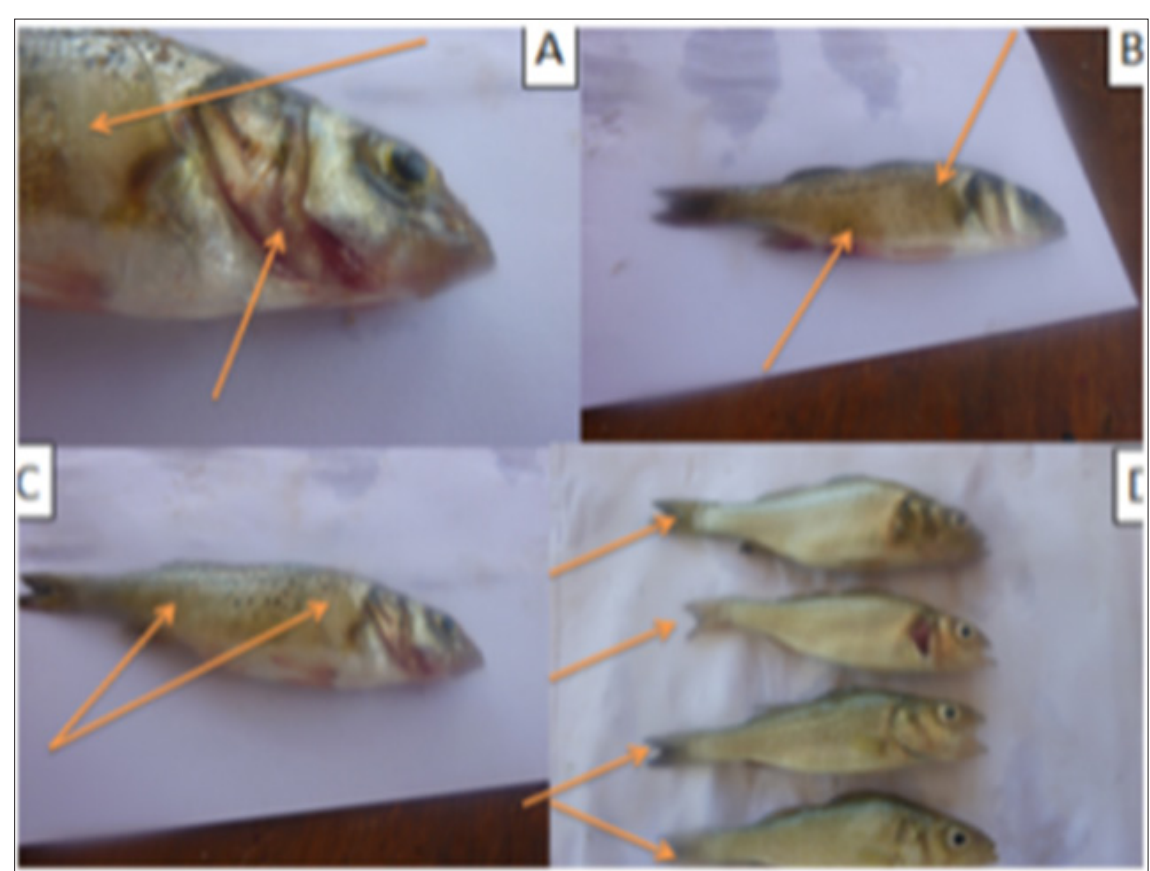

Figure 1: Sea bass infested by Gyrodactylus sp and Dactylogyrus sp and Cryptocaryon irritansshowedareas of scale loss and may ooze a pinkish fluid and white spot (blister-like raised lesions along the body) (A\&B\&C) and gills may be swollen and pale (D). 
Results of clinical signs of sea bass and sea bream infested by Cryptocaryon irritans showed white spot disease" has been a problem to aquarists for generations. Fish infected with this organism typically develop small blister-like raised lesions along the body wall and/or fins. If the infection is restricted to the gills, no white spots will be seen. The gills will appear swollen and be covered with thick mucus. Identification of the parasite on the gills, skin, and/or fins is necessary to conclude that fish has an "ich" infection. The mature parasite (Figure 1) is very large, up to 1000 $\mu \mathrm{m}$ in diameter, is very dark in color due to the thick cilia covering the entire cell, and moves with an amoeboid motion (Figure 2).

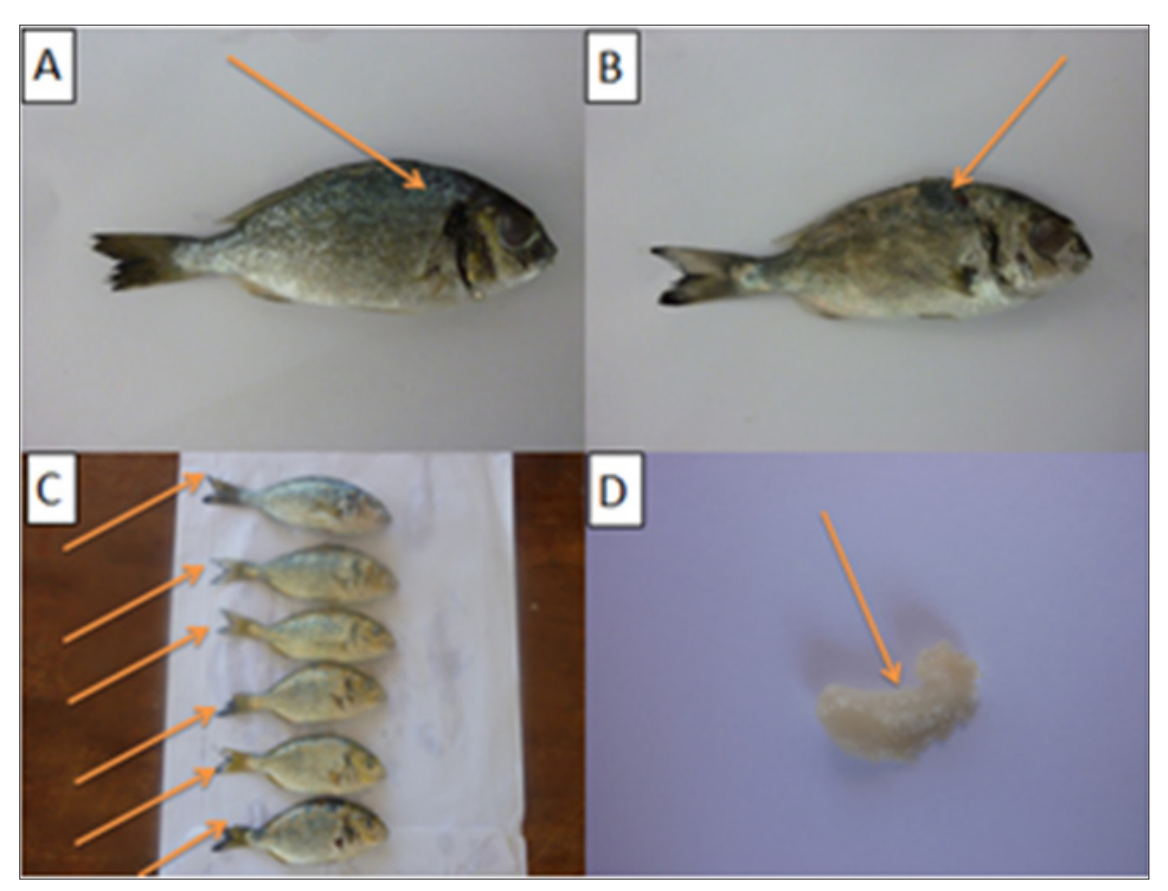

Figure 2: Sea bream infested by Gyrodactylus sp and Dactylogyrus sp and Cryptocaryonirritants howed sloughing of scales, ulcer formation and white spot (blister-like raised lesions along the body) (A\&B\&C) and gills may be swollen and pale (D).

\section{Results of parasitic examination}

a) Monogenic Trematodes Gyrodactylus spand Dactylogyrus spare the two most common genera of monogeneans that infect freshwater fish (Figure 3 A, B, C\& D). They differ in their reproductive strategies and their method of attachment to the host fish. Gyrodactylus have no eyespots, two pairs of anchor hooks, and are generally found on the skin and fins of fish. They are live bearers (viviparous) in which the adult parasite can be seen with a fully developed embryo inside the adult's reproductive tract. This reproductive strategy allows populations of Gyrodactylus to multiply quickly, particularly in closed systems where water exchange is minimal.

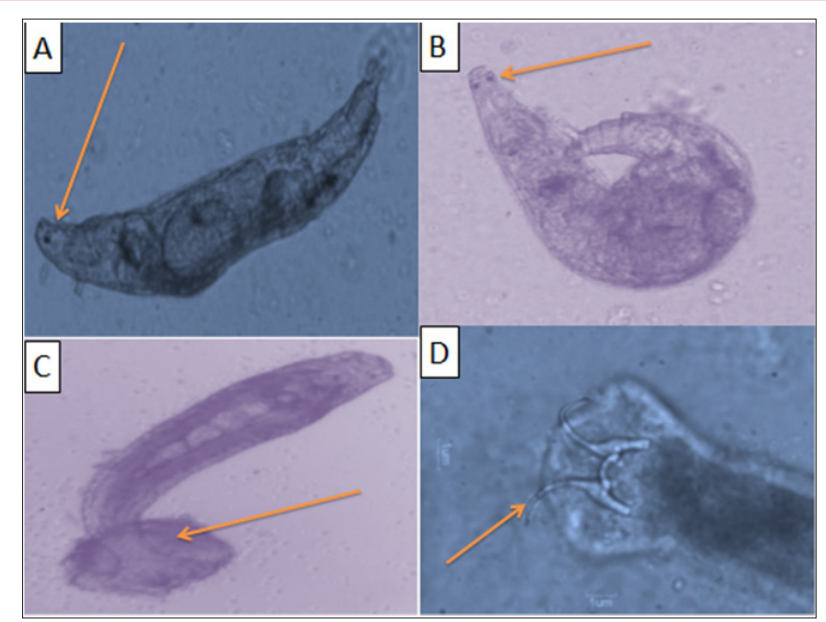

Figure 3: (A) Wet mount of the sea bass and sea bream gills during infection with Gyrodactylus sp(40x), (B) Wet mount of the sea bass and sea bream skin during infection with Dactylogyrus sp $(40 \mathrm{x})(\mathrm{C})$ Wet mount of the sea bass gills and skin during infection with Dactylogyrussp with distinct marginal hooks (40x) (D) Wet mount of the sea bass and sea bream gills during infection with Dactylogyrussp. With distinct marginal hooks (40 xs). 
b) Cryptocaryon irritans: Classically, Cryptocaryon irritansis identified by its large horseshoe-shaped macronucleus. This feature is not always readily visible, however, and should not be the sole criterion for identification. Immature forms of Cryptocaryon irritansare smaller and more translucent in appearance (Figure 4).

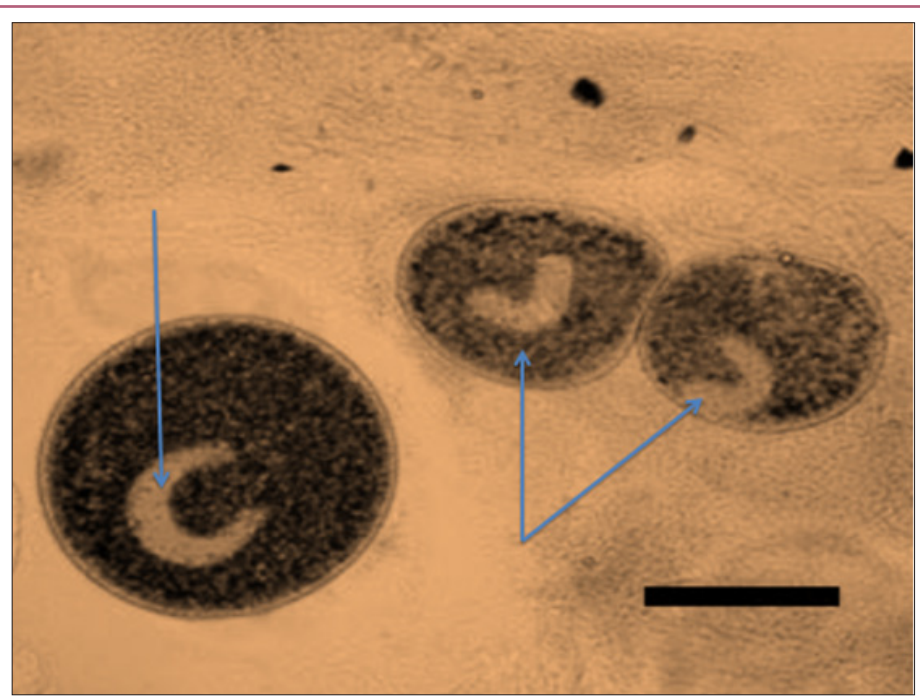

Figure 4: Wet mount of the sea bass and sea bream skin during infection with Cryptocaryon irritans (Note the C-shape nucleus) (40x)

Parasitic Frequency Index (PFI) and prevalence of Gyrodactylus sp and Dactylogyrus sp and Cryptocaryon irritansin sea bass and sea bream during different seasons

a) Parasitic Frequency Index (PFI) and prevalence of Gyrodactylus sp and Dactylogyrus sp in sea bass and sea bream during different seasonsit was observed that among sea bream highly susceptible species more than sea bass to the monogenean parasites (Figure 3). The Parasitic Frequency Index (PFI) was calculated (Table 3) for these two parasites in sea bream and sea bass. Prevalence and severity of monogenean parasites in sea bass and sea bream were recorded (Table 4). During the study highest infestation with Dactylogyrus sp in the summer season in sea bass and sea bream $(70.00 \%$ and $86.67 \%)$, while the Gyrodactylus sp. lowest in the winter season $(6.67 \%$ and $16.67 \%$ ) in the sea bass and sea bream respectively.

Table 3: Parasitic frequently index (PFI) and severity of monogenic parasites present during summer and inter season of 2016 in sea bass and sea bream.

\begin{tabular}{|c|c|c|c|c|c|c|c|c|c|c|c|c|}
\hline \multirow{3}{*}{ Fish } & \multirow{2}{*}{\multicolumn{2}{|c|}{$\begin{array}{c}\text { No. of } \\
\text { Infected fishes }\end{array}$}} & \multicolumn{10}{|c|}{ Parasitic data } \\
\hline & & & \multicolumn{2}{|c|}{$\begin{array}{c}\text { Monogenic } \\
\text { Parasites present }\end{array}$} & \multicolumn{2}{|c|}{$\begin{array}{l}\text { No. ofInfected } \\
\text { fishes }\end{array}$} & \multicolumn{2}{|c|}{ PFI (\%) } & \multicolumn{2}{|c|}{ Siteof infection } & \multicolumn{2}{|c|}{$\begin{array}{l}\text { Severity of } \\
\text { infection }\end{array}$} \\
\hline & $\mathbf{S}$ & w & $\mathbf{S}$ & w & $S$ & w & $\mathbf{S}$ & $\mathbf{w}$ & S & W & S & w \\
\hline Sea bass & 30 & 30 & $\begin{array}{c}\text { Dactylogyrus } \\
\text { sp. }\end{array}$ & $\begin{array}{c}\text { Gyrodactylus } \\
\text { sp. }\end{array}$ & 21 & 2 & 70 & 6.67 & Gill\&Skin & Skin & 3 & 0.5 \\
\hline $\begin{array}{c}\text { Sea } \\
\text { bream }\end{array}$ & 30 & 30 & $\begin{array}{c}\text { Dactylogyrus } \\
\text { sp. }\end{array}$ & $\begin{array}{c}\text { Gyrodactylus } \\
\text { sp. }\end{array}$ & 26 & 5 & 86.67 & 16.67 & Gill\&Skin & Skin & 3 & 1 \\
\hline
\end{tabular}

S: Summer season W: Winter season.

Table 4: Mean \pm SD based on the prevalence (\%) of monogenean parasites during summer and winter season of 2016.

\begin{tabular}{|c|c|c|c|}
\hline \multicolumn{2}{|c|}{ Mean \pm SD } & Parasites & \multirow{2}{*}{ Fish species } \\
\cline { 1 - 2 } Winter season & Summer season & Dactylogyrus $s p$. & Sea bass \\
\hline $9.2 \pm 1.58$ & $44.75 \pm 25.81$ & Gyrodactylus $s p$. & \multirow{2}{*}{ Sea bream } \\
\hline $23.46 \pm 7.34$ & $7.98 \pm 1.24$ & Dactylogyrus $s p$. & Gyrodactylus $s p$. \\
\hline
\end{tabular}

Cite this article: Khalil R, Medhat S S, Hanan A G, Khallaf M, Sherif E S. Seasonal Parasitic Infestations and their Close Relationship to 
b) Parasitic Frequency Index (PFI) and prevalence of Cryptocaryon irritans in sea bass and sea bream during different seasons

c) It was observed that among sea bream highly susceptible species more than sea bass to the Cryptocaryon irritans (Figure 4). The C. irritans Frequency Index (PFI) was calculated (Table
5) for C. irritans in sea bream and sea bass. Prevalence and severity of monogenean parasites in sea bass and sea bream were recorded (Table 6). During the study highest infestation with C. irritans in the winter season in sea bass and sea bream (56.67\% and $96.67 \%$ ), while the C. irritans lowest in the summer season $(3.33 \%$ and $6.67 \%)$ in the sea bass and sea bream respectively.

Table 5: Parasitic frequently index (PFI) of C. irritans parasites present during summer and winter season of 2016 in sea bass and sea bream.

\begin{tabular}{|c|c|c|c|c|c|c|c|c|}
\hline \multirow{3}{*}{ Fish } & \multirow{2}{*}{\multicolumn{2}{|c|}{$\begin{array}{c}\text { No. of } \\
\text { Infected fishes }\end{array}$}} & \multicolumn{6}{|c|}{ Parasitic data } \\
\hline & & & \multicolumn{2}{|c|}{$\begin{array}{l}\text { No. oflnfected fishes with C. } \\
\text { irritans }\end{array}$} & \multicolumn{2}{|c|}{ PFI (\%) } & \multicolumn{2}{|c|}{ Site of infection } \\
\hline & $\mathbf{S}$ & $\mathbf{w}$ & S & w & S & $\mathbf{w}$ & S & w \\
\hline Sea bass & 30 & 30 & 1 & 17 & 3.33 & 56.67 & Skin\& Gill & Skin\& Gill \\
\hline Sea bream & 30 & 30 & 2 & 29 & 6.67 & 96.67 & Skin\& Gill & Skin\& Gill \\
\hline
\end{tabular}

Table 6: Mean \pm SD based on the prevalence (\%) of Cryptocaryon irritans parasites during summer and winter season of 2016.

\begin{tabular}{|c|c|c|}
\hline \multicolumn{2}{|c|}{ Mean \pm SD } & \multicolumn{2}{c}{ Fish species } \\
\hline Winter season & Summer season & Sea bass \\
\hline $59.66 \pm 8.29$ & $3.17 \pm 0.57$ & Sea bream \\
\hline
\end{tabular}

d) Results of immune parameters: The mean values of total protein; albumin; globulin and lysozyme activity of parasitized and Non-Parasitizedsea bass and sea bream revealed decrease of total protein; globulin and lysozyme activity in parasitized sea bass and sea bream compared to non- parasitized fish (Table 7).

Table 7: Total protein, albumin and globulins of parasitized and Non- parasitized sea bream and sea bass.

\begin{tabular}{|c|c|c|c|}
\hline Samples & Total protein mg/l & Albumin gm.\% & Lysozyme activity (units/ \\
ml)
\end{tabular}

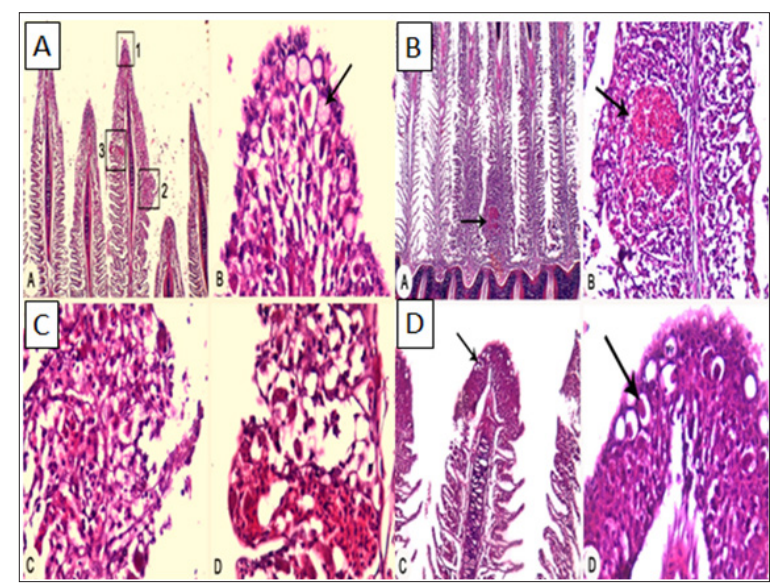

Figure 5: (A) Gills of infected sea bass showing parasitic infestation at the gill's tip (square 1), granulomatous inflammation (square 2) and hemorrhages in gill's lamellae (square 3) X40. (B) Gills of infected sea bass showing parasitic infestation, embedded trophonts (arrow), at the gill's tip. X40. (C) Gills of infected sea bream showing granulomatous inflammation in gill's lamellae which associated with inflammatory cell infiltration and fusion the lamellae X40. (D) Gills of infected sea bream showing parasitic infestation, embedded trophonts (arrow), at the gill's tip. HE stains X40. 


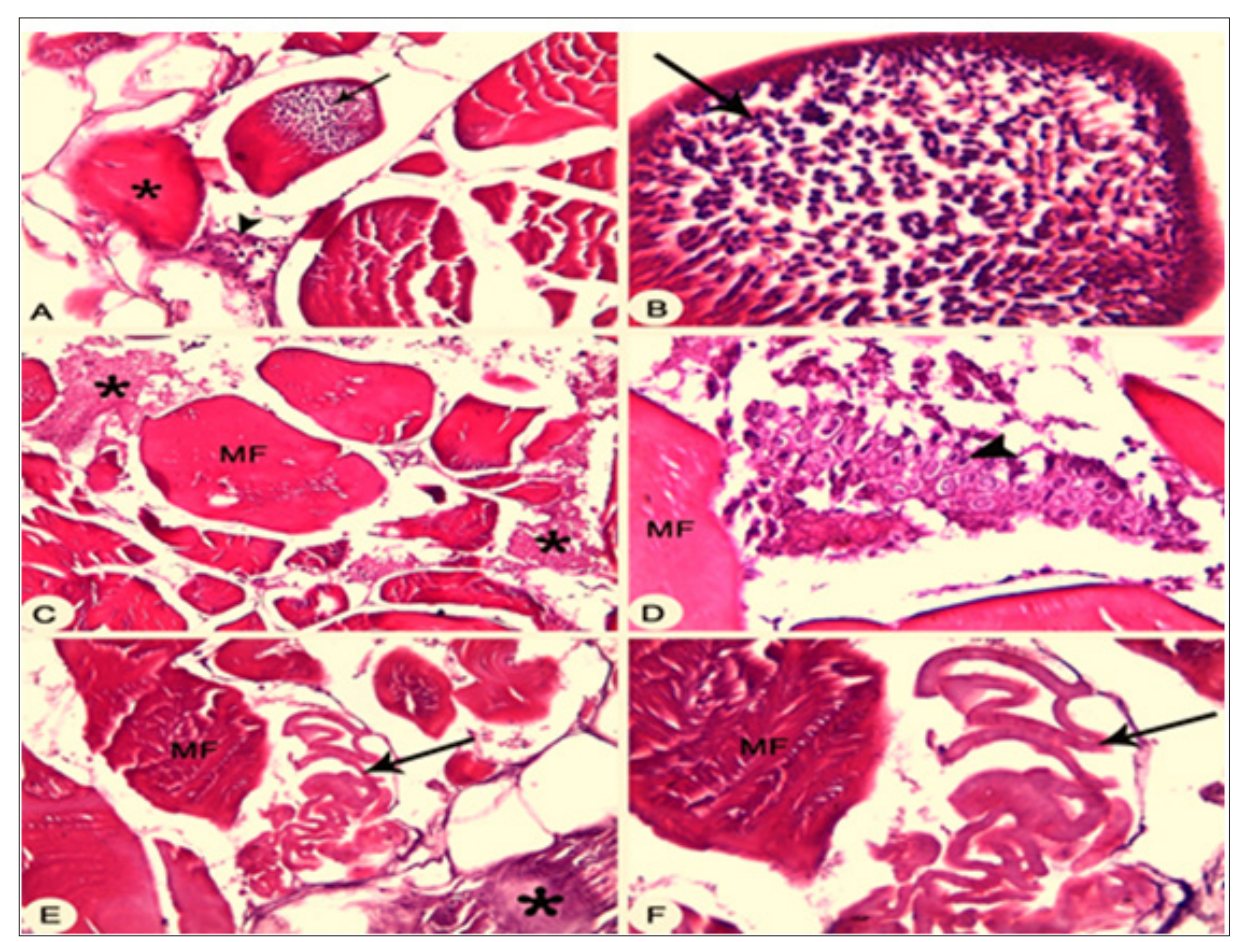

Figure 6: :(A\&B) Skin and Musculature of infected sea bass showing infestation of protozoan parasite inside the skeletal muscle fiber (arrow), degenerated myofibril (asterisk) and interstitial myocytis (arrowhead) X100. (C\&D) Skin and Musculature of infected sea bream showing parasitic interstitial myocytis (asterisk) with the presence of protozoan trophozoite (arrowhead) X40. (E\&F) Skin and Musculature of infected sea bream showing infestation of parasite in between muscle bundles (arrow) and degenerated myofibril (asterisk) X40.

e) Histopathological findings: Gills of infected sea bass and sea bream showing parasitic infestation at the gill's tip, granulomatous inflammation also showing parasitic infestation, embedded trophonts (Figure 5), at the gill's tip also, and showing parasitic infestation, embedded trophonts. Skin and musculature in infested fish revealed presence of protozoan parasite inside the skeletal muscle fiber and presence of protozoan trophozoite in between muscle bundles (Figure 6).

\section{Discussion}

a) The prevalent parasite identified in sea bass and sea bream samples examined from the cultured environments were Dactylogyrus sp, Gyrodactylus sp and Cryptocaryon irritans. Tables 1 represents the prevalence parasites in the skin and gills of cultured fish samples. During the study highest infestation with Dactylogyrus sp in the summer season in sea bass and sea bream (70.00\% and 86.67\%), while the Gyrodactylus sp. lowest in the winter season (6.67\% and $16.67 \%)$, while on contrary the highest infestation with C. irritans in the winter season in sea bass and sea bream (56.67 \% and 96.67\%), while the C. irritans lowest in the summer season (3.33\% and 6.67 $\%$ ) in cultured sea bass and sea bream respectively.

b) In relation to the season incidence of $\mathrm{C}$ Irritans increase in the winter season this can be due to high rain influx during the rainy season and low rain influx during the dry season. It is also supported according to Morenikeji and Adepeju [24] who reported that fishes are susceptible to heavy infestation with parasites mainly in the early rain when fishes are weakened by hibernation (a state of exhaustion). On the same manner Avenant-Oldewage[6] mentioned that the deaths of fish seeds were mainly due to extreme low and high temperature of winter and summer respectively. Parasitic infections often give an indication of the quality of water since parasites generally increase in abundance and diversity in more polluted waters. The parasitic community of fish show considerable variation with the environmental conditions in which fish live [7] Grabda [25] and El-Seify et al. [26] stated that the high incidence and prevalence of parasitism during summer season than in winter season in both species.Also, reported that the high incidence of parasites occurs especially in areas with deteriorations of the water quality. On the other hand Reed et al., 2005 noted that some parasites were reported on separate season, as in summer season Gyrodactylus, were isolated, while in the winter season the researcher recorded that the Dactylogyrus and Cryptocaryon were found.

c) Temperatures for optimal growth of most strains of Cryptocaryon appear to be about $23-30^{\circ} \mathrm{C}[27]$, although active infections at $15^{\circ} \mathrm{C}$ have been documented [28]. A more recent study demonstrated that two life stages of one strain of Cryptocaryon (trophonts, i.e., the feeding stage during which the parasite can be found on the fish and tomonts) survived dormant for $4-5$ months at $12^{\circ} \mathrm{C}$, and, after the water temperature increased to $27^{\circ} \mathrm{C}$, developed and infected fish [8].

d) The mean values of total protein; albumin; globulin and lysozyme activity stated during the present study revealed 
that decrease of total protein; globulin and lysozyme activity in parasitized sea bass and sea bream compared to nonparasitizedsea bass and sea bream (Table 7).

On contrary Burgess and Matthews [19] stated fish that survive a Cryptocaryon infection develop immunity, which can prevent significant disease for up to 6 months. However, these survivors may act as carriers and provide a reservoir for future outbreaks [23]. [19]Proved that common carp can stimulate the immune system during infestation with light intensity of ecto parasites.

\section{References}

1. Burgess PJ, RA Matthews (1995) Cryptocaryon irritans(Ciliophora) acquired protective immunity in the thick-lipped mullet, Chelonlabrosus. Fish and Shellfish Immunology 5(6): 459-468.

2. Thrusfield B (1997) Studies on some parasitic affection in fresh water fishes in Beni-Suef Governorate. P.D.V. Sc. Thesis, Cairo University.

3. Cowx IG (1992) Aquaculture development in Africa, training and reference manual for aquaculture extensionists Food production and rural development. Common wealth secretariat London, Pp: 246-295.

4. Saha H (2009) Occurrence, distribution and pathology of monogenetic gill parasites in Labeorohita(Hamilton). MVSc Thesis College of fisheries. Central Agricultural University. Tripura. India.

5. Murray AG, Peeler EJ (2005) A frame work for understanding the potential for emerging diseases in aquaculture. Preventive Veterinary Medicine 67(2-3): 223-235.

6. Avenant Oldewage A (2002) Protocol for the assessment of fish health based on the Health index Report and manual for training of field workers to the Rand Water Board Report no. 2001/03/03/13. BIOM. GEN. (H1) Rand Water Vereeniging.

7. Hossain MD, Hossain MK, Rahaman MH, Akter A, Khanom DA (2008) Prevalence of ectoparasites of carp fingerlings at Santaher, Bogra. University Journal of Zoology 27:17-19.

8. Ivona M (2004) Monogenean parasites in Adriatic cage-reared fish. Acta Adriatica. 5:65-73.

9. Koskivaara M, Valtonen ET (1992) Dactylogyrous (Monogenea) communities on the gills of the roach in the three lakes in central Finland. Parasitologia 104(2): 263-272.

10. Bychowsky BE (1957) Monogenetic trematodes, their systematic and phylogeny (English translation), Washington: American Institute of Biological Science Pp: 509.

11. Yambot AV, YL Song, HH Sung (2003) Characterization of Cryptocaryon irritans, a parasite isolated from marine fishes in Taiwan. Diseases of Aquatic Organisms 54(2): 147-156.

12. Yoshinaga T (2001) Effects of high temperature and dissolved oxygen concentration on the development of Cryptocaryon irritans(Ciliophora) with a comment on the autumn outbreaks of Cryptocaryoniasis. Fish Pathology 36(4): 231-235.

13. Dan XM, XT Lin, YX Yan, N Teng, ZL Tan, AX Li (2009) A technique for the preservation of Cryptocaryonirritansat low temperatures. Aquaculture 297(1-4): 112-115.
14. Docan A, Cristae V, Dedin L, Grecu I (2012) Studies of Europeancatfish (Silurus glanis) leucocytes reaction in condition of rearing inflow-thru aquaculture. Lucrări Ştiinţifice Zootehnie, 53: 417-423.

15. Yang JL, Chen HC (2003) Effects of gallium on common carp (Cyprinus carpio): acute test, serum biochemistry and erythrocyte morphology. Chemosphere 53(8): 877-882.

16. Patriche T, Patriche N, Bocioc E, Coada MT (2011) Serum biochemical parameter of farmed carp (C. carpio). International J. theBioflux Society 4(2): 131-140.

17. Maqsood S, Samoon MH, Singh P (2009) Immunomodulatory andgrowth promoting effect of dietary levamisole in Cyprinus carpiofingerlings against the challenge of Aeromonas hydrophila. TurkishJournal of Fisheries and Aquaculture Sciences 9: 111-120.

18. Shahsavani D, Kaxerani H, Kaveh S, Kanani H (2010) Determination of some normal serum parameters in starry Sturgeon (Acipenserstellatus) during spring season. Comp. Clin. Pathol 19: 57-61.

19. Ahmed SM, Ali AH (2013) Serum proteins and leucocytes differential count in the common carp infested with ectoparasites. J Mar Sci 28(2): 151-162.

20. Srivastava CB (1980) Estimation of helminthic infections. Proceedings Workshop Technology Parasitol. Zoological Survey of India. Pp: 29-31.

21. Margolis L, Esch GW, Holmes JC, Schod GA (1982) The use of ecological terms in parasitology. Report of an ad-hoc Committee of the American Society of Parasitologists. Journal of parasitology 68: 131-133.

22. Bush AO, Lafferty KD, Lotz JM, Shostak AW (1997) Parasitology meets ecology on its own terms: Margolis et al. Revisited. Journal of parasitology 83(4): 575-583.

23. Morenikeji AK, Adepeju GS (2009) Diurnal variations of physic-chemical factors and Planktonic organism in Jos Plateau (W. Africa) water reservoir. Japanese journal of Limnology 44 (1): 65-71.

24. Grabda J (1989) Marine Fish Parasitology: An Outline. Polish Scientific Publishers, Warszawa.

25. El Seify MA, Mona S Zaki, Abdel Razek Y Desouky, Hossam H Abbas Osman K, et al. (2011) Seasonal variations and prevalence of some external parasites affecting freshwater fishes reared at upper Egypt. Life Science Journal 2011: 8(3).

26. Dickerson HW (2006) Ichthyophthirius multifiliis and Cryptocaryon irritans (Phylum Ciliophora) pp. 116-153.

27. Diggles BK, RJG Lester (1996) Influence of Temperature and Host Species on the development of Cryptocaryon irritans. The Journal of Parasitology Vol 82(1): 45-51.

28. Arthur JR, Bondad Reantaso MG, Subasinghe RP, Ogawa K, Chinabut S, Adlard, et al. (2005) Disease and health management in acian aquaculture. Veterinary parasitology 132(3-4): 249-272.

29. Kurva RR, Gadadhar D (2013) Prevalence of Monogenean Parasites on Indian Major Carps in Bheries of West Bengal. IJCBS 4:13-21.

30. Mo TA (1992) Seasonal variations in the prevalence and infestation intensity of Gyrodactylus salaris Malmberg, 1957 (Monogenea: Gyrodactylidae) on Atlantic salmon parr, Salmo salar L. in the River Batnfjordselva. Journal of Fish Biology 42: 697-707.

31. Reed P, Francis Floyd R, Klinger R (2005) Monogenean parasites of fish .University of Florida PP- 1-5. 
ISSN: 2574-1241

DOI: 10.26717/BJSTR.2018.06.001376

Khalil RH. Biomed J Sci \& Tech Res

(C) This work is licensed under Creative

Submission Link: https://biomedres.us/submit-manuscript.php

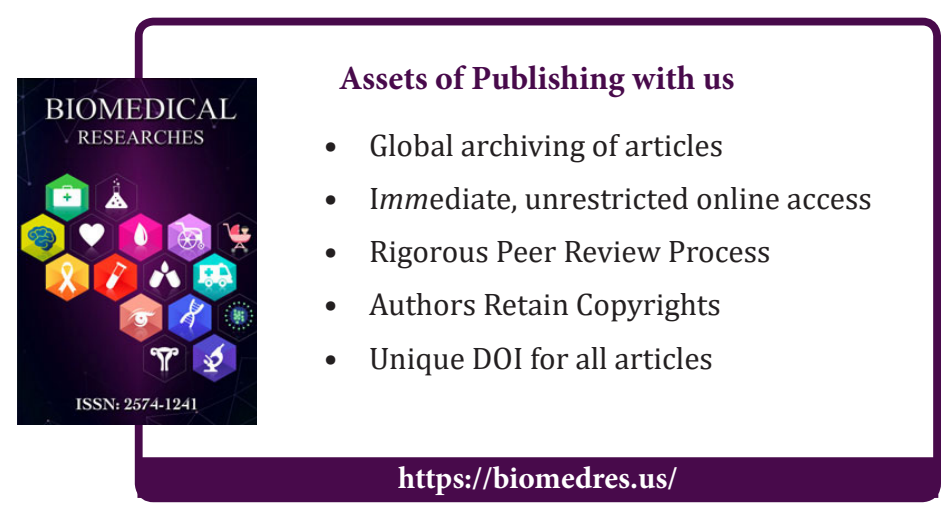

